\title{
Neuropharmacological Evaluation of the Putative Anxiolytic Effects of Passiflora edulis Sims, its Sub-fractions and Flavonoid Constituents
}

\author{
Miguel Coleta ${ }^{1}$, Maria Teresa Batista ${ }^{1}$, Maria Graça Campos $^{1}$, Rui Carvalho ${ }^{2}$, Maria Dulce \\ Cotrim $^{3}$, Thereza Christina M. de Lima* and António Proença da Cunha ${ }^{4}$ \\ ${ }^{1}$ Center of Pharmaceutical Studies, Laboratory of Pharmacognosy, Universidade de Coimbra, 3000 Coimbra, Portugal \\ ${ }^{2}$ Department of Biochemistry/Center for Neuroscience, Universidade de Coimbra, 3000 Coimbra, Portugal \\ ${ }^{3}$ Laboratory of Pharmacology, Faculty of Pharmacy, Universidade de Coimbra, 3000 Coimbra, Portugal \\ ${ }^{4}$ Laboratory of Neuropharmacology, Department of Pharmacology, CCB, Universidade Federal de Santa Catarina, Florianópolis, \\ 88015-420, SC, Brazil
}

\begin{abstract}
Passiflora edulis Sims together with several other plants of the genus Passiflora have been reported to possess anxiolytic properties. It has been suggested recently that flavonoids may be partly responsible for the neuropharmacological activity of these plants but there are still few data reporting the relation between the constituents of these plants and their activity. This work evaluated the anxiolytic/sedative activity of an aqueous extract of Passiflora edulis Sims and bioguided its fractionation using the elevated plus-maze model of anxiety and other complementary pharmacological tests. The aqueous extract presented an anxiolytic-like activity without any significant effect upon the motor activity whilst the total flavonoid fraction (TFF) presented an anxiolytic-like activity but compromised motor activity. Through fractionation of TFF it was possible to isolate and characterize luteolin-7-0-[2-rhamnosylglucoside] which showed an anxiolytic-like activity without compromising motor activity. Copyright (c) 2006 John Wiley \& Sons, Ltd.
\end{abstract}

Keywords: Passiflora edulis Sims; flavonoid glycosides; anxiety; elevated plus-maze; luteolin-7-O-[2-rhamnosylglucoside].

\section{INTRODUCTION}

Passiflora incarnata L. is the one Passifloraceae most commonly used in Europe for its anxiolytic/sedative properties and is referred to as the medicinal species in different official publications (ESCOP, German Commission E Monographs). Despite this fact there have been several reports over the years on the anxiolytic/ sedative activity of various other species of the genus Passiflora, namely P. edulis Sims (Petry et al., 2001), P. coerulea L. (Wolfman et al., 1994), P. alata Curtis (Oga et al., 1984). These studies carried out with different animal models generally show insufficient characterization of the extracts and/or botanical materials used and this has brought some controversy on which of the Passiflora genus species do possess any neuropharmacological activity and which are the active constituents involved in it (Dhawan et al., 2004).

Passiflora edulis Sims is the edible variety most commonly known for its tasty fruit but also reported

\footnotetext{
* Correspondence to: Miguel Coleta, R. dos Girassóis, 258, 2785-725 S. Domingos de Rana, Lisboa, Portugal.

E-mail: mcoleta@netcabo.pt

Contract/grant sponsor: Praxis XXI; contract/grant number: BD/16264/ 98 .
}

to be used in Brazilian traditional folk medicine (Maluf et al., 1991; Vale and Leite, 1983) and to be active in animal models of anxiety (Petry et al., 2001). This plant is widely available in Portugal as a garden plant or a crop and previous work by some members of our group showed that $P$. edulis Sims aqueous extracts had significant affinity for $5-\mathrm{HT}_{3}$ rat brain receptors thus suggesting an eventual anxiolytic activity (Cotrim et al., 1995). As it has been suggested that flavonoids may play a role in the neuropharmacological activity of several plants (Medina et al., 1997; Paladini et al., 1999) including $P$. incarnata L. (Zanoli et al., 2000) and $P$. coerulea L. (Wolfman et al., 1994) we wanted to establish if the aqueous extract of Passiflora edulis Sims growing in Portugal and the flavonoids it contains had any activity in classical animal models of anxiety using properly characterized extracts and also to isolate and identify those flavonoid constituents possibly involved in this activity.

Two non-conditioned tests were chosen that are well accepted for determining the anxiolytic-like activity of these preparations in mice: the elevated plus-maze (EPM) (Lister, 1987; Rodgers and Cole, 1994; Rodgers and Dalvi, 1997) and the marble-burying test (MBT) (Broekkamp et al., 1986). To evaluate any eventual effects on motor activity the wire test (Boissier et al., 1961) and the chimney test (Boissier et al., 1960) were chosen. 


\section{METHODS}

Plant material. Leaves from plants growing wild in Beira Litoral, Portugal, were used. The leaves were collected during the flowering season, dried in a flow of hot air $\left(25^{\circ} \mathrm{C}\right)$, ground and stored below $-10{ }^{\circ} \mathrm{C}$. A properly identified voucher specimen of the starting plant material, Passiflora edulis Sims, was deposited in the Botanical Institute, University of Coimbra and referenced by the author's name.

Flavonoids extraction and fractionation. A $6 \%(\mathrm{w} / \mathrm{v})$ infusion was prepared by adding boiling water to the powder sample. The filtered infusion was stirred, for $1 \mathrm{~h}$ with Amberlite XAD 2 (BDH Laboratory Reagents) and the phenolic compounds fixed in this resin were eluted with $\mathrm{MeOH}$ and $75 \% \mathrm{MeOH}$. Both eluates were mixed and concentrated to dry residue, which was re-dissolved in $75 \% \mathrm{MeOH}$ and chromatographed on Sephadex LH-20 (Sigma, 25-100 $\mu \mathrm{m})$. All fractions collected were monitored by TLC (silica gel), EtOAc/ $\mathrm{HCOOH} / \mathrm{H}_{2} \mathrm{O}$, 9:1:1, detection under $\mathrm{UV}_{354 \mathrm{~nm}}$ before and after the action of ammonia vapour and after spraying with the reagent NEU/PEG (Markham, 1989). Fractions exhibiting the typical flavonoid profile were pooled and concentrated to dryness resulting in the total flavonoid fraction (TFF).

The TFF was chromatographed on Whatman $3 \mathrm{~mm}$ paper, EtOAc/HCOOH$/ \mathrm{H}_{2} \mathrm{O}, \quad 44: 16: 20$. The three distinct absorption bands observed under $\mathrm{UV}_{354 \mathrm{~nm}}$ were cut out and eluted with $50 \%-100 \% \mathrm{MeOH}$ to yield three flavonoid subfractions: SF I, SF II and SF III. SF I was subsequently chromatographed on Whatman ${ }^{\circledR}$ $3 \mathrm{~mm}$ paper, HOAc $15 \%$ and the two distinct $\mathrm{UV}_{354 \mathrm{~nm}}$ absorption bands (compounds $\mathrm{A}$ and $\mathrm{B}$ ) were cut out and eluted with $\mathrm{MeOH}$. The residue of these eluates was dissolved in water and purified with Isolute ${ }^{\circledR}$ C18 pre-packed columns.

Analytical procedures. The composition of the infusion, TFF, SF I, SF II, SF III, A and B was analysed by HPLC using a Gilson ${ }^{\circledR}$ apparatus, a reverse phase column $\left(250 \times 4 \mathrm{~mm}\right.$; Spherisorb ${ }^{\circledR}$ S5 ODS 2) and a Nucleosil ${ }^{\circledR}$ C18 pre-column (particle size $5 \mu \mathrm{m} ; 30 \times$ $4 \mathrm{~mm}$ ). Gradient 1: linear gradient of $\mathrm{MeOH} / 5 \%$ $\mathrm{HCOOH}(35 \%$ to $80 \%$ in $60 \mathrm{~min})$ with a flow rate of $1 \mathrm{~mL} / \mathrm{min}$. Gradient 2: water $\left(\mathrm{pH}=2.2\right.$ with $\left.\mathrm{H}_{3} \mathrm{PO}_{4}\right)$ (A)/acetonitrile (B) (0-12 min: $100 \%-91 \%$ of $\mathrm{A}$; 12-20 min: $91 \%-87 \%$ of A; $20-40 \mathrm{~min}: 87 \%-67 \%$ of A; $40-42 \min : 67 \%$ of A; $42-52 \min : 67 \%-57 \%$ of $\mathrm{A}$; $52-60 \mathrm{~min}$ : $57 \%$ of A) with a flow of $0.8 \mathrm{~mL} / \mathrm{min}$. Peak detection and absorption spectra were obtained with a Gilson ${ }^{\circledR} ' 170$ diode array detector' (Campos et al., 1997). The infusion and the TFF were screened for the presence of tannins and alkaloids. For tannins TLC (silica gel) was used with $\mathrm{CHCl}_{3} / \mathrm{EtOAc} / \mathrm{HCOOH}$, 5:4:1, detection with $5 \%$ phosphomolybdic acid in $\mathrm{MeOH}$ after heating at $80^{\circ} \mathrm{C}$ during $10 \mathrm{~min}$. For alkaloid screening the procedure recommended by French Pharmacopoeia $\mathrm{X}$ was followed. The flavonoid contents of the different fractions were determined according to the Passiflora incarnata L. monograph in French Pharmacopoeia X.

NMR spectra of the two isolated compounds and their hydrolysates (dissolved in $600 \mu \mathrm{L} \mathrm{DMSO}-\mathrm{d}_{6}$ ) were recorded in a Varian Unity-500 spectrometer using either a $5 \mathrm{~mm}$ reverse detection $\left({ }^{1} \mathrm{H}-\mathrm{NMR}, \mathrm{HMBC}\right.$ and COSY) or a $5 \mathrm{~mm}$ broadband probe $\left({ }^{13} \mathrm{C}-\mathrm{NMR}\right)$.

Acid hydrolysis of compounds $\mathrm{A}$ and $\mathrm{B}$ was performed (Markham, 1989) and the genin was analysed by HPLC and co-chromatographed with standard luteolin and orientin, purchased from Extrasynthése (Genay, France).

Pharmacological assays. Adult male Swiss mice (25$35 \mathrm{~g}$ ) were used. Animals were housed in a local animal house in groups of ten animals per plastic cage, with a controlled dark/light $12 \mathrm{~h}$ cycle (lights on at 07:00 h) and food was supplied ad libitum. Each animal was used just once. All experiments were conducted in accordance with international standards of animal welfare recommended by the Brazilian Society of Neuroscience and Behavior (Act 1992) and the experimental protocols were approved by the University Committee for Animal Care in Research (\#23080.001156/2001-50/ UFSC). The minimum number of animals and the duration of observation required to obtain consistent data were used.

The animals were orally administered, using an intragastric cannula (by gavage), with the different test solutions, diazepam or distilled water (vehicle) $60 \mathrm{~min}$ before testing. To ascertain the best time-course for observation, the infusion and TFF were previously tested with $30,60,90$ and 120 min delays before the testing. On the test day, mice were placed in the laboratory $1 \mathrm{~h}$ prior to the experiment, which was always conducted during the same period of the day (09.00$13.00 \mathrm{~h}$ ). The lyophilized infusion was restored with water immediately before testing and doses were evaluated in the range between 14.4 and $230 \mathrm{mg} / \mathrm{kg}$. TFF, SF (I, II, III), A and B were also dissolved in distilled water and tested in doses corresponding to its percentage in the extract from which they were obtained. Complementary doses ranging from 1 to $100 \mathrm{mg} / \mathrm{kg}$ were also tested. Diazepam was used in a dose of $1 \mathrm{mg} / \mathrm{kg}$ and extemporaneous solutions were prepared by slowly diluting a commercial diazepam formulation (Valium ${ }^{\circledR}$ Roche $/ 5 \mathrm{mg}$ ) in distilled water immersed in an ultrasound bath.

Elevated plus-maze test (EPM). The elevated plus-maze was slightly modified from that used by Lister (1987). Briefly, it consisted of two open arms $(30 \times 5 \times 0.25 \mathrm{~cm})$ and two enclosed arms $(30 \times 5 \times 15 \mathrm{~cm})$, extending from a central platform $(5 \times 5 \mathrm{~cm})$ and arranged so that two pairs of identical arms were opposite to each other. The apparatus was raised to a height of $50 \mathrm{~cm}$ above floor level. The maze floor was constructed from black Plexiglas and the walls from clear Plexiglas. At the beginning of the test, each mouse was placed on the central platform facing an enclosed arm. After the test (5 min), the maze was carefully cleaned with wet tissue paper (10\% ethanol solution). Mouse behaviour was recorded under red light illumination $(15 \mathrm{~W})$ by using a video-camera located $100 \mathrm{~cm}$ above the maze. Tapes were analysed 'blind' for the treatment used. The conventional spatiotemporal measures were the number of entries (all four paws on open or enclosed arms and expressed as the percentage of total entries), the time spent on open arms (expressed as the percentage of time spent on closed plus open arms), number of entries on enclosed arms and the time on the central 
platform. Ethologically derived measures were grooming, rearing, stretched attend postures (SAP), headdipping (HD) and defaecation as an emotionally related parameter (Rodgers and Dalvi, 1997; Espejo, 1997). A selective increase in the spatiotemporal parameters of exploration of the open arms of the maze reveals an anxiolytic-like effect (Pellow et al., 1985).

Marble-burying test (MBT). This test consisted of a Plexiglas cage of $23 \times 17 \times 14 \mathrm{~cm}$ with a smooth lid punctured by small ventilation holes. The floor was covered with a $5 \mathrm{~cm}$ layer of sawdust and 25 glass marbles were placed in contact with each other in the centre of the maze. The mouse was placed in the cage for $30 \mathrm{~min}$ after which it was removed and the burying response quantified by counting the number of marbles that were more than two thirds covered with sawdust. A diminution of the burying reflex reveals a positive anxiolytic-like effect (Broekkamp et al., 1986).

Motor performance evaluation. Muscle relaxant effects were evaluated using the horizontal-wire test which consisted of a stretched copper wire placed $20 \mathrm{~cm}$ above the ground (Boissier et al., 1961). The animal is suspended in the wire by its fore paws and the time taken for the animal to reach the wire with the hind paws or tail is counted. Animals who failed to do it within $5 \mathrm{~s}$ were considered to have failed the test and this was considered to be synonymous with muscle relaxation (Vogel and Vogel, 1997).

Motor coordination was assessed using the chimney test which consisted of a simple glass tube in which the experimental mouse entered and when it reached the other end, the tube was placed in a vertical position. The normal reaction of the animal was to climb the tube backwards. Animal performance was evaluated by the time taken to reach the upper edge of the glass tube considering motor impairment the inability of the mouse to climb backwards up the tube within $30 \mathrm{~s}$ (Boissier et al., 1960).

Statistical analysis. Statistical analysis of the results obtained was done with GraphPad Instat ${ }^{\circledR}$ software, using ordinary ANOVA followed by post-hoc Tukey's test for comparisons between treatments and Fisher's exact test for the Horizontal-wire and chimney tests. Differences between the experimental groups were considered statistically significant when $p<0.05$.

\section{RESULTS}

\section{Flavonoid extraction and analytical procedures}

Infusions of Passiflora edulis Sims leaves were found to contain $2.45 \pm 0.1 \%(\mathrm{w} / \mathrm{w})$ of flavonoids expressed in rutin. The TLC control of the fractionation process on Sephadex LH-20 revealed the presence of a majority of compounds with strong $\mathrm{UV}_{354 \mathrm{~nm}}$ absorption, yellow/ greenish fluorescence after exposure to ammonia vapour and yellow/orange fluorescence after revelation with NEU/PEG thus suggesting a flavone type structure (Markham, 1989). This fractionation procedure yielded $1.4 \pm 0.3 \%(\mathrm{w} / \mathrm{w})$ of $\mathrm{TFF}$ which presented a flavonoid content of $60 \pm 0.2 \%(\mathrm{w} / \mathrm{w})$. Tannin screening

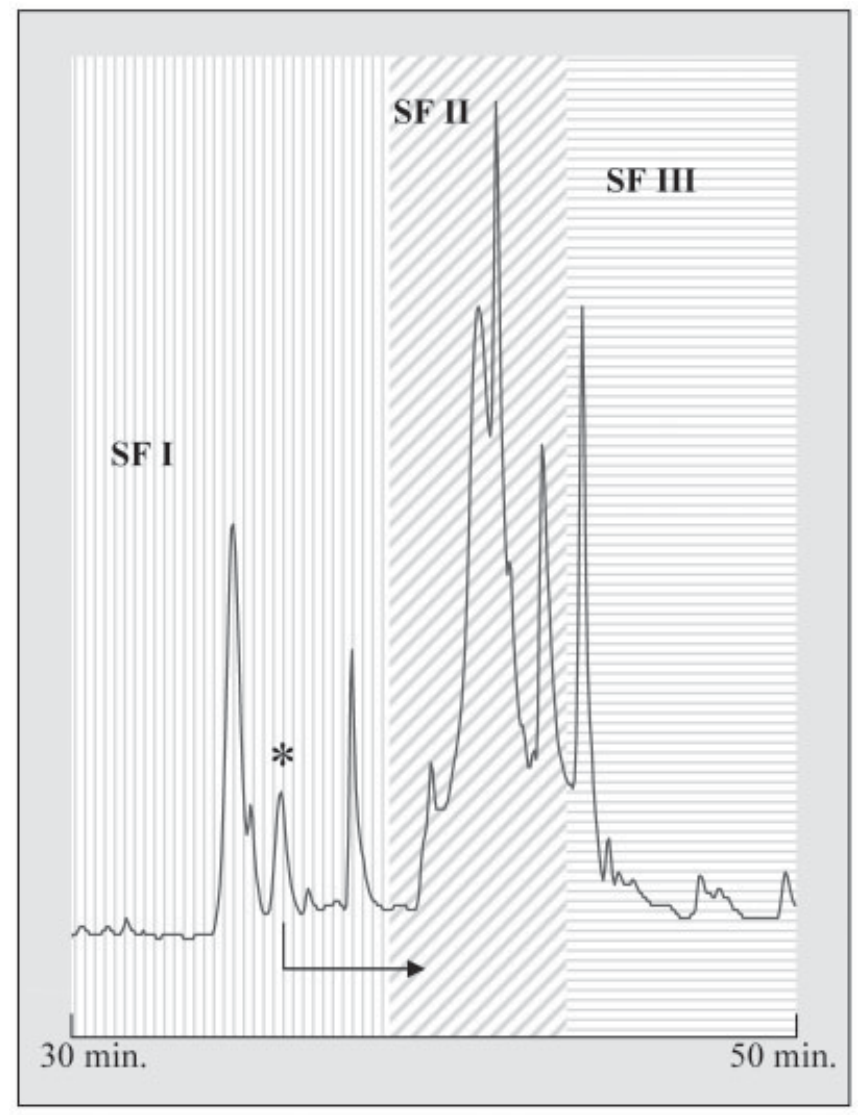

Figure 1. Schematic representation of a total flavonoid fraction (TFF) HPLC chromatogram (Gradient 2; detection: $340 \mathrm{~nm}$ ), signalling each sub-fraction (SF I, II and III) constituents obtained after preparative paper chromatography (PC) of TFF.

was positive for the infusion but negative for TFF. Alkaloids were absent from the infusion as well as from TFF.

Preparative PC of TFF yielded three sub-fractions: SF I $[17.3 \%(w / w)]$, SF II $[51.8 \%(w / w)]$ and SF III $[11.4 \%(\mathrm{w} / \mathrm{w})]$ and their HPLC profiles were established (Fig. 1). The different chromatograms (HPLC, PC) of SF I have shown that it was composed of two compounds: A [retention time $\left(R_{\mathrm{t}}\right)=37.4 \mathrm{~min}$ (gradient 2) and $R_{\mathrm{t}}=9.4 \mathrm{~min}$ (gradient 1$\left.)\right]$ and $\mathrm{B}\left(R_{\mathrm{t}}=34.5 \mathrm{~min}\right.$ (gradient 2) and $R_{\mathrm{t}}=10.8 \mathrm{~min}$ (gradient 1). PC of SF I with HOAc $15 \%$ allowed the isolation of compound $\mathrm{A}$ [20.3\% (w/w); retention factor $\left.\left(R_{\mathrm{f}}\right)=0.29\right]$ and compound B $\left[72.1 \%(\mathrm{w} / \mathrm{w}) ; R_{\mathrm{f}}=0.58\right]$. After acid hydrolysis, A presented the same $R_{\mathrm{t}}$ (gradient $1=28.1 \mathrm{~min}$; gradient $2=49.5 \mathrm{~min}), R_{\mathrm{f}}(\mathrm{PC} / \mathrm{HOAc} 70 \%: 0.56)$ and UV spectrum (absorption maxima: 245sh, 254, 267, $291 \mathrm{sh}, 349 \mathrm{~nm}$ ) as standard luteolin. After acid hydrolysis B presented the same $R_{\mathrm{t}}$ (gradient 1: 9.4 min; gradient 2: $34.9 \mathrm{~min})$ and $R_{\mathrm{f}}(\mathrm{PC} / \mathrm{HOAc} 15 \%: 0.15)$ as pure standard orientin and its UV absorption maximums were also superimposable (255, 266, 292sh, $348 \mathrm{~nm})$.

\section{NMR analysis of compounds $A$ and $B$}

Compound A - ${ }^{1} \mathrm{H}-\mathrm{NMR}$ (500 MHz, DMSO-d6): $\delta$ $(\mathrm{ppm})=7.45\left(1 \mathrm{H}, \mathrm{d}, J=2.2 \mathrm{~Hz}, \mathrm{H}-6^{\prime}\right), 7.40(1 \mathrm{H}, \mathrm{s}$, H-2') 6.90 (1H, d, $\left.J=8.4 \mathrm{~Hz}, \mathrm{H}-5^{\prime}\right), 6.77$ (2H, s, H-3, $\mathrm{H}-8), 6.37$ (1H, d, H-6), $5.24(1 \mathrm{H}, \mathrm{d}, J=7.3 \mathrm{~Hz}$, H-1Glc), 5.13 (1H, s, H-1 Rha). After hydrolysis: 7.42 
Table 1. Time course of the behavioural effects tested in the EPM

\begin{tabular}{|c|c|c|c|c|c|c|c|c|}
\hline & \multicolumn{2}{|c|}{$\begin{array}{l}30 \text { min } \\
\text { Plus-maze }\end{array}$} & \multicolumn{2}{|c|}{$\begin{array}{l}60 \text { min } \\
\text { Plus-maze }\end{array}$} & \multicolumn{2}{|c|}{$\begin{array}{l}90 \text { min } \\
\text { Plus-maze }\end{array}$} & \multicolumn{2}{|c|}{$\begin{array}{l}120 \text { min } \\
\text { Plus-maze }\end{array}$} \\
\hline & $\% O E$ & $\% O T$ & $\% \mathrm{OE}$ & $\% O T$ & $\% \mathrm{OE}$ & $\%$ OT & $\% O E$ & $\% O T$ \\
\hline Vehicle & $21.3 \pm 5.8$ & $19.4 \pm 8.6$ & $18.3 \pm 4.5$ & $16.3 \pm 6.6$ & $14.5 \pm 10.5$ & $13.6 \pm 11.1$ & $20.8 \pm 6.7$ & $14.2 \pm 10.2$ \\
\hline Diazepam & $25.5 \pm 13.4$ & $30.3 \pm 16.5$ & $49.9 \pm 14.7^{b}$ & $54.8 \pm 12.8^{b}$ & $44.8 \pm 17.6^{\mathrm{a}}$ & $47.8 \pm 19.8^{a}$ & $33.9 \pm 16.8$ & $43.2 \pm 15.0^{\mathrm{a}}$ \\
\hline TFF & $22.5 \pm 16.4$ & $14.6 \pm 9.3$ & $43.4 \pm 16.5^{\mathrm{a}}$ & $40.1 \pm 12.1^{b}$ & $39.4 \pm 12.2^{\mathrm{a}}$ & $37.3 \pm 8.4^{\mathrm{b}}$ & $29.6 \pm 12.4$ & $34.3 \pm 14.4$ \\
\hline Infusion & $30.3 \pm 9.5$ & $23.4 \pm 7.5$ & $36.9 \pm 9.3^{\mathrm{a}}$ & $35.3 \pm 10.1^{\mathrm{a}}$ & $29.8 \pm 4.3^{\mathrm{a}}$ & $25.1 \pm 5.2$ & $30.1 \pm 7.4$ & $14.5 \pm 12.3$ \\
\hline
\end{tabular}

Behavioural effects 30, 60, 90 and 120 min after administration of vehicle, diazepam, TFF and infusion.

$\% \mathrm{OE}, \%$ number of entries in the open areas of the plus-maze vs total number of entries; \%OT, \% time spent in the open areas of the plus-maze. Data presented as mean \pm SEM. Statistical analysis, a $p<0.05,{ }^{b} p<0.001$ with ANOVA and Tukey's test.

$\left(1 \mathrm{H}, \mathrm{s}, \mathrm{H}-2^{\prime}\right), 7.39\left(1 \mathrm{H}, \mathrm{d}, J=2.3 \mathrm{~Hz}, \mathrm{H}-6^{\prime}\right), 6.88(1 \mathrm{H}, \mathrm{d}$, $\left.J=8.4 \mathrm{~Hz}, \mathrm{H}-5^{\prime}\right), 6.67$ (1H, s, H-3), 6.45 (1H, s, H-6), $6.19(1 \mathrm{H}, \mathrm{s}, \mathrm{H}-8) .{ }^{13} \mathrm{C}-\mathrm{NMR}\left(500 \mathrm{MHz}, \mathrm{DMSO}-\mathrm{d}_{6}\right): \delta$ $(\mathrm{ppm})=94.4$ [Glucose $(\mathrm{G}) 1], 73.3(\mathrm{G} 2), 72.3(\mathrm{G} 3), 77.3$ (G4), 72.4 (G5), 60.3 (G6), 99.3 [Rhamnose (R)1], 77.2 (R2), 77.0 (R3), 76.4 (R4), 71.9 (R5), 18.1 (R6).

Compound $\mathrm{B}-{ }^{1} \mathrm{H}-\mathrm{NMR}\left(500 \mathrm{MHz}, \mathrm{DMSO}-\mathrm{d}_{6}\right)$ : $\delta$ $(\mathrm{ppm})=13.14(1 \mathrm{H}, \mathrm{s}, 5-\mathrm{OH}), 7.55(1 \mathrm{H}, \mathrm{d}, J=8.5 \mathrm{~Hz}$, H-6'), 7.49 (1H, s, H-2'), $6.87\left(1 \mathrm{H}, \mathrm{d}, J=8.4 \mathrm{~Hz}, \mathrm{H}-5^{\prime}\right)$, $6.66(1 \mathrm{H}, \mathrm{s}, \mathrm{H}-3), 6.26(1 \mathrm{H}, \mathrm{s}, \mathrm{H}-6), 4.98(1 \mathrm{H}, \mathrm{s}$, H-1 Rha), $4.75(1 \mathrm{H}, \mathrm{d}, J=9.9 \mathrm{~Hz}, \mathrm{H}-1 \mathrm{Glc})$. After hydrolysis: $\delta(\mathrm{ppm}) 7.54\left(1 \mathrm{H}, \mathrm{d}, J=8.4, \mathrm{H}-6^{\prime}\right), 7.48(1 \mathrm{H}$, s, H-2') $6.87\left(1 \mathrm{H}, \mathrm{d}, J=8.4 \mathrm{~Hz}, \mathrm{H}-5^{\prime}\right), 6.65(1 \mathrm{H}, \mathrm{s}, \mathrm{H}-$ 3), $6.27(1 \mathrm{H}, \mathrm{s}, \mathrm{H}-6), 4.67(1 \mathrm{H}, \mathrm{d}, J=9.0, \mathrm{H}-1 \mathrm{Glc}) .{ }^{13} \mathrm{C}-$ NMR (500 MHz, DMSO-d $\left.{ }_{6}\right): \delta(\mathrm{ppm})=71.5(\mathrm{G} 1), 75.1$ (G2), 80.0 (G3), 70.4 (G4), 82.0 (G5), 61.5 (G6), 100.4 (R1), 70.9 (R2), 70.5 (R3), 71.7 (R4), 68.3 (R5), 17.8 (R6).

\section{Pharmacological studies}

When testing the infusion and TFF to determine the most suitable time-course for the observation of the behavioural effects (Table 1), positive results were found (i.e. statistical significant differences with relation to groups administered only with vehicle-distilled water) were observed after 60 min of the oral administration. After $90 \mathrm{~min}$, the results were less significant and after 120 min there was a general increase in the dispersion of the results. Therefore, all other results presented in this paper were obtained 60 min after oral administration of all test solutions.

For the lyophilized infusion doses were tested between 5 and $230 \mathrm{mg} / \mathrm{kg}$. Only the highest dose $(230 \mathrm{mg} /$ $\mathrm{kg}$ ) produced a statistical significant increase in both the percentage of time spent and the number of entries into the open arms of the EPM in relation to the group administered with vehicle (Fig. 2). Also, in the MBT there was a significant diminution of the object-burying reflex only at the highest dose $(230 \mathrm{mg} / \mathrm{kg}$; Fig. 3). In the range of doses tested for the infusion there were no significant changes in the parameters evaluated in the wire and chimney tests (Fig. 4).

For TFF doses between 1 and $100 \mathrm{mg} / \mathrm{kg}$ were tested. For the dose corresponding to the active dose of the infusion $(3.2 \mathrm{mg} / \mathrm{kg})$ there were no significant changes in any of the tests. However, with $100 \mathrm{mg} / \mathrm{kg}$ there was an increase in the percentage of entries and the time spent in the open arms of the EPM (Fig. 2). Results of the horizontal wire test showed an increase in the percentage of animals considered to be under muscle

\section{Elevated Plus Maze}

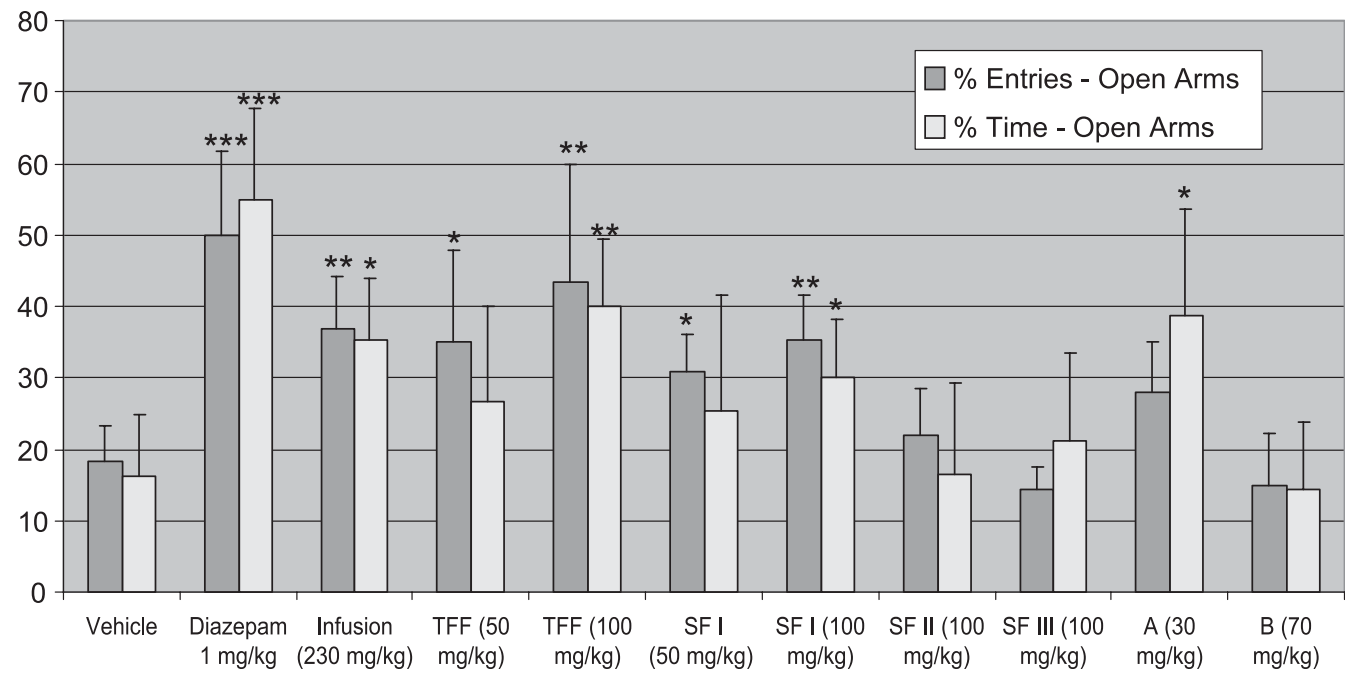

Figure 2. Analysis of the behaviour of mice in the elevated plus maze test of anxiety. Results expressed as average ( \pm SEM) percentage of entries in the open areas of the maze (closed bars) and average percentage of time in the open areas of the maze (hatched bars). ${ }^{* *} p<0.001 ;{ }^{* *} p<0.01 ; * p<0.05$ are significantly different from control (ANOVA; Tukey's test). The number of mice per group ranged between 9 and 16 . 


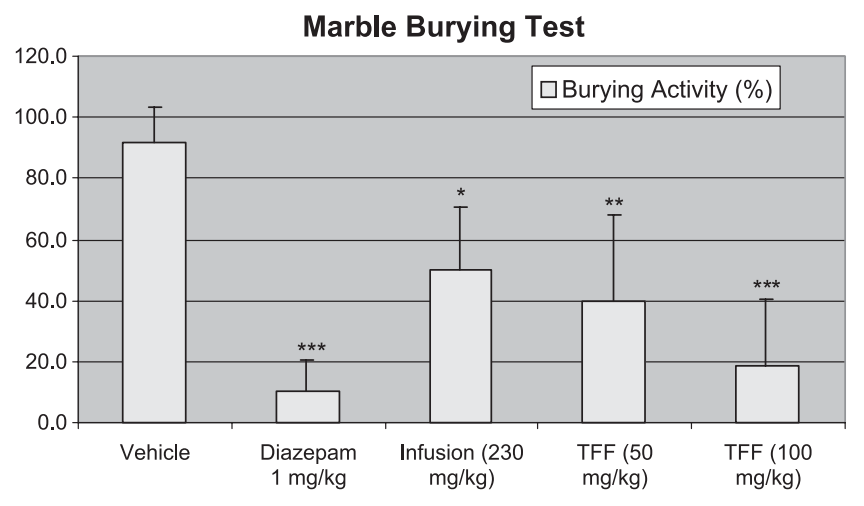

Figure 3. Behavior of mice in the marble burying test. Results expressed as average percentage ( \pm SEM) of buried marbles. *** $p<0.001 ; * * p<0.01 ; * p<0.05$ are significantly different from control (ANOVA; Tukey's test). The number of mice per group ranged between 8 and 11 .

relaxant effects and an increase in the percentage of animals presenting motor uncoordination in the chimney test (Fig. 4). With both 50 and $100 \mathrm{mg} / \mathrm{kg}$ a reduction of the marble-burying reflex was observed (Fig. 3).

With SF I, II and III there were no positive results in any of the tests when a dose corresponding to the active dose of TFF $(100 \mathrm{mg} / \mathrm{kg})$ was used. But when higher doses were tested, SF I significantly increased the time spent $(100 \mathrm{mg} / \mathrm{kg})$ and the number of entries $(50$ and $100 \mathrm{mg} / \mathrm{kg}$ ) in the open arms of the plus-maze (Fig. 2), without any effect on motor activity parameters (Fig. 4). SF II (10-100 mg/kg) and SF III (1-100 mg/kg) induced no significant changes in any of the tests used.
With compounds A (0.3-30 mg/kg) and B (0.7$100 \mathrm{mg} / \mathrm{kg})$, isolated from SF I, only A $(30 \mathrm{mg} / \mathrm{kg})$ significantly increased the percentage of time spent in the open arms of the EPM (Fig. 2) and none of them induced any effects on the motor activity tests (Fig. 4).

Analysis of the ethological parameters in the EPM was performed only for SF I, II, III and compounds A and $\mathrm{B}$ (Table 2). The only significant differences were found for SF I and compound A. SF I decreased the number of total stretch approach postures (SAP) with 50 and $100 \mathrm{mg} / \mathrm{kg}$, whereas it also increased the total number of head-dippings. Compound A (30 mg/kg) significantly increased the number of head-dips.

\section{DISCUSSION}

The elevated plus-maze is now widely accepted as an animal model of anxiety (Reibaud and Böhme, 1993). The ratio of the number of entries into the open arms to the total number of arm entries and the ratio of the time spent in the open arms to the time spent in both types of arms are used as markers of the natural aversion of rodents for the open arms and these two parameters have been shown to be increased by clinically effective anxiolytics and to be decreased by anxiogenic drugs (Lister, 1987; Pellow et al., 1985). The defensive burying is a behaviour that can be elicited in rodents in response to aversive stimuli and inhibited by diazepam or chlordiazepoxide (Treit et al., 1981). Glass marbles provide an effective unconditioned stimulus

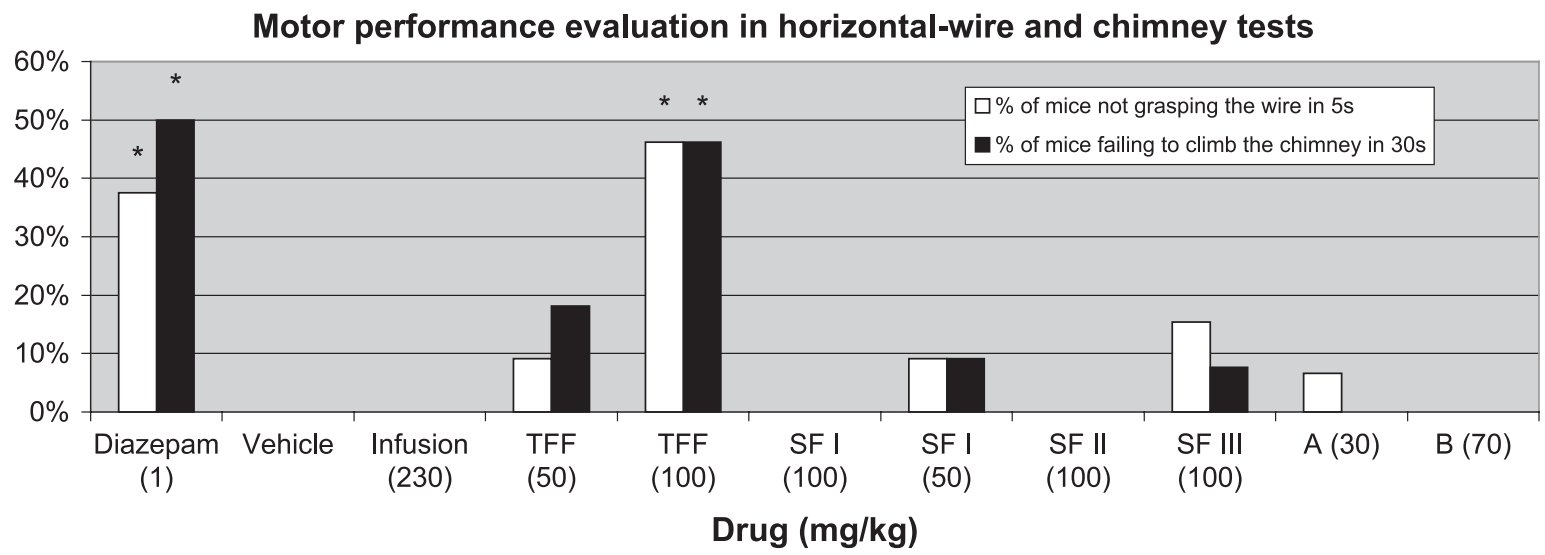

Figure 4. Performance of mice in the horizontal-wire and in the chimney test: mice who failed to grasp the wire with their hind paws in $5 \mathrm{~s}$ were considered to be under a myorelaxant effect and those who failed to climb the chimney backwards in $30 \mathrm{~s}$ were considered to be motor uncoordinated. ${ }^{*} p<0.001$ significantly different from control, Fisher's exact test. The number of mice per group ranged between 11 and 16 .

Table 2. Analysis of ethological parameters in the EPM

\begin{tabular}{lcc}
\hline & $\begin{array}{c}\text { Protected } \\
\text { head-dips }(\%)\end{array}$ & $\begin{array}{c}\text { Total stretched } \\
\text { attend postures }\end{array}$ \\
\hline Vehicle $(n=13)$ & $72.1 / 6.7$ & $16.2 / 3.8$ \\
Diazepam $(1 \mathrm{mg} / \mathrm{kg})(n=11)$ & $50.1 / 11.2^{\mathrm{b}}$ & $6.8 / 2.1^{\mathrm{b}}$ \\
$\mathrm{SF} \mathrm{I}(100 \mathrm{mg} / \mathrm{kg})(n=10)$ & $60.3 / 5.4^{\mathrm{a}}$ & $6.4 / 2.5^{\mathrm{b}}$ \\
$\mathrm{SF} \mathrm{I}(50 \mathrm{mg} / \mathrm{kg})(n=9)$ & $68.2 / 7.3$ & $7.3 / 5.7^{\mathrm{a}}$ \\
$\mathrm{A}(30 \mathrm{mg} / \mathrm{kg})(n=9)$ & $58.6 / 6.5^{\mathrm{a}}$ & $17.3 / 8.0$ \\
$\mathrm{~B}(70 \mathrm{mg} / \mathrm{kg})(n=10)$ & $70.1 / 9.2$ & $18.4 / 7.1$ \\
\hline
\end{tabular}

Data presented as mean/SEM. Statistical analysis ${ }^{a} p<0.05 ;{ }^{b} p<0.001$ with ANOVA and Tukey's test. 
which provokes burying (Poling et al., 1981) and this model has been used for the screening of anxiolyticlike drugs with the diminution of the burying activity indicating an anxiolytic-like effect (Broekkamp et al., 1986). Therefore the results obtained with $P$. edulis Sims infusions in the EPM and MBT are consistent with an anxiolytic-like effect. As there were no significant changes on the motor activity parameters measured by the wire and the chimney tests it was concluded that this anxiolytic-like effect was devoid of any effects on motor activity.

TFF also revealed an anxiolytic-like activity in both EPM and MBT parameters but unlike the infusion and despite the number of entries into the enclosed arms of the EPM [parameter directly related with motor activity (Rodgers and Cole, 1994)] remaining unchanged, the results obtained in the wire and in the chimney tests indicate muscle relaxant effects with motor impairment. As TFF is mainly composed of flavonoids and tested negatively for other possible active substances, such as tannins or alkaloids (Takahashi et al., 1986; Aoagy et al., 1974), it was concluded that the flavonoids extracted from $P$. edulis Sims could be involved in the neuropharmacological activity. However, as the doses (50 and $100 \mathrm{mg} / \mathrm{kg}$ ) necessary to induce positive effects were much higher than the TFF content in the active dose of the infusion and the pharmacological profile was also different a possible direct or indirect involvement of other compounds in the activity of the infusion cannot be ruled out.

Ethological derived parameters such as protected head-dipping or stretched attend postures are risk assessment measures inversely related with an anxiolytic effect and are generally more sensitive to drug action than the traditional indices of anxiety in this test (Rodgers and Cole, 1994). Hence it can be concluded that the SF I $(50,100 \mathrm{mg} / \mathrm{kg})$ increase in the conventional spatiotemporal parameters of open arms exploration and decrease of head-dipping and stretched attend postures is consistent with an anxiolytic-like effect. However, SF I did not have any effect on MBT which can be described as a model of novelty-induced or proximal threat anxiety, whereas EPM is a model of approach-avoidance conflict. It is known that the same compound may act at different dose ranges in distinct models (Olivier et al., 2000), however, the differences obtained spanned all the dose ranges tested and this aspect should be further investigated.

The positive results of SF I obtained in the EPM were observed for doses much higher than the corresponding dose of the active extract from which it was obtained thus suggesting that other compounds in TFF could also be involved in its neuropharmacological activity. The same doses did not elicit any effect on the motor activity measured in the EPM and by the chimney and wire tests, hence indicating a specific anxiolyticlike effect without sedation or muscle relaxation.

When both isolated components of SF I were tested it was verified that only compound A $(30 \mathrm{mg} / \mathrm{kg})$ induced changes in both classical and ethological derived parameters of the EPM, consistent with an anxiolyticlike effect which in this case correlated very well with its content in the active dose of SF I $(100 \mathrm{mg} / \mathrm{kg})$.

${ }^{1} \mathrm{H}-\mathrm{NMR}$ analysis of SF I isolated constituents, revealed that both compound $\mathrm{A}$ and $\mathrm{B}$, were substituted flavones. Through the assignment of ${ }^{13} \mathrm{C}$-NMR signals and from HMBC and COSY correlations, the type and relative position of the sugar residues in the flavone nucleus were established. The results were consistent with the structure of luteolin-7-O-[2-rhamnosylglucoside] (compound A) and 8-C-glucosylluteolin2"-rhamnoside (compound B). This leads to the conclusion that if the $\mathrm{C}$-linked rhamnoglucosyl appears in position 8 of the flavone nucleus this can negatively affect the neuropharmacological activity.

Recently Dhawan et al. (2004) questioned the correct identification of the Passiflora species used in previous studies and attributed the discrepancy in the literature to this fact. These authors also reported on a comparison of $P$. incarnata L. with $P$. edulis Sims in the elevated plus-maze test of anxiety concluding that $P$. edulis Sims was devoid of pharmacological activity (Dhawan et al., 2001). Although it is agreed that in some cases there is a strong possibility of mistaken identity between $P$. incarnata L. and $P$. edulis Sims due to their morphological resemblance, it is not believed that this assumption can be used to simply rule out all the anxiolytic-like activity reports of other Passifloraceae. Instead it is believed that the apparent discrepancy between our results and those of Dhawan is surely a consequence of the differences in the chemical composition of the plant extracts used, maybe originating in the processing and extraction procedures of the botanical materials or even in the different $P$. edulis Sims chemotypes used by each group.

Although we did not identify all the active constituents in P. edulis Sims and our results cannot be used to justify the medicinal use of this plant, this study clearly demonstrated that this plant's aqueous extracts and flavonoids did have anxiolytic-like activity and that at least one of these flavonoids, luteolin-7-O-[2rhamnosylglucoside], can elicit the same kind of neuropharmacological activity.

\section{Acknowledgement}

M. Coleta was a recipient of a PhD Scholarship from Praxis XXI (BD/16264/98)

\section{REFERENCES}

Aoagy N, Kimura R, Murata T. 1974. Studies on Passiflora incarnata dry extract. I. Isolation of maltol and pharmacological action of maltol and ethyl maltol. Chem Pharm Bull 22: $1006-1013$.

Boissier JR, Dremont C, Robins R, Pagny J. 1961. Tentative de pharmacology prévisionnelle dans le domaine des neuroleptiques: actions sedative centrale et adrénolytique de la $\mathrm{N}$ (diméthoxy-3,4 phénéthyl) $\mathrm{N}^{\prime}$ (chloro-2-phényl)piperazine. Arch Int Pharmacodyn Ther 133: 29-32.
Boissier JR, Tardy J, Diverres JC. 1960. Une nouvelle méthode simple pour explorer I'action 'tranquillisante': le test de la cheminée. Med Exp 3: 81-84.

Broekkamp CL, Rijk W, Joly-Gelouin D. 1986. Major tranquilizers can be distinguished from minor tranquilizers on the basis of effects on marble burying and swim-induced grooming in mice. Eur J Pharmacol 126: 223-229.

Campos M, Markham KR, Mitchell KA, da Cunha AP. 1997. An approach to the characterization of bee pollens via 
their flavonoid/phenolic profiles. Phytochem Anal 8: 181185.

Cotrim MD, Martins MA, Figueiredo IV et al. 1995. Effects of Passiflora edulis aqueous extracts on 5-HT3 receptors in guinea-pig ileum and rat brain. Pharmacol Res Suppl. EPHAR (Proceedings of the Federation of European Pharmacological Societies): 266.

Dhawan K, Dhawan S, Sharma A. 2004. Passiflora: a review update. J Ethnopharmacol 94: 1-23.

Dhawan K, Kumar S, Sharma A. 2001. Comparative biological activity study on Passiflora incarnata and $P$. edulis. Fitoterapia 72: 698-702.

Espejo EF. 1997. Structure of the mouse behaviour on the elevated plus-maze test of anxiety. Behav Brain Res 86: 105-112.

Lister RG. 1987. The use of a plus-maze to measure anxiety in the mouse. Psychopharmacology 92: 180-185.

Maluf E, Barros MT, Frochtengarten ML, Benti R, Leite JR. 1991. Assessment of the hypnotic/sedative effects and toxicity of Passiflora edulis aqueous extract in rodents and humans. Phytother Res 5: 262-266.

Markham KR. 1989. Plant phenolics. In Methods in Plant Biochemistry, Vol. 1, Dey PM, Harborne JB (eds). Academic Press: London, 202-203.

Medina JH, Viola H, Wolfman C et al. 1997. Overview Flavonoids: a new family of benzodiazepine receptor ligands. Neurochemistry 22: 419-425.

Oga S, Freitas PCD, Silva AG, Hanada S. 1984. Pharmacological trials of crude extract of Passiflora alata. Planta Med 50: 303-306.

Olivier B, van Wijngaarden I, Soudijn W. 2000. 5 HT-3 receptor antagonists and anxiety, a pre-clinical and clinical review. Eur Neuropsychopharmacol 10: 77-95.

Paladini AC, Marder M, Viola H, Wolfman C, Wasowski C, Medina JH. 1999. Flavonoids and the central nervous system: from forgotten factors to potent anxiolytic compounds. J Pharm Pharmacol 51: 519-526.
Pellow S, Chopin P, File SE, Briley M. 1985. Validation of open closed arm entries in an elevated plus-maze as a measure of anxiety in the rat. $J$ Neurosci Meth 14: 149-167.

Petry RD, Reginatto F, de-Paris F et al. 2001. Comparative pharmacological study of hydroethanol extracts of Passiflora alata and Passiflora edulis leaves. Phytother Res 15: 162164.

Poling A, Cleary J, Monaghan M. 1981. Burying by rats in response to aversive and nonaversive stimuli. J Exp Anal Behav 35: 31.

Reibaud M, Böhme GA. 1993. Evaluation of putative anxiolytics in the elevated plus-maze test. Methods Neurosci 14: 230 239.

Rodgers RJ, Cole JC. 1994. The elevated plus-maze: pharmacology, methodology and ethology. In Ethology and Psychopharmacology, Cooper SJ, Hendrie CA (eds). John Wiley \& Sons: New York, 9-44.

Rodgers RJ, Dalvi A. 1997. Anxiety, defense and the elevated plus-maze. Neurosci Biobehav Rev 21: 801-810.

Takahashi RN, Lima TCM, Morato GS. 1986. Pharmacological actions of tannic acid; II. Evaluation of CNS activity in animals. Planta Med 4: 272-275.

Treit D, Pinel JPJ, Fibiger HC. 1981. Conditioned defensive burying: a new paradigm for the study of anxiolytic agents. Pharmacol Biochem Behav 15: 619.

Vale NB, Leite JR. 1983. Efeitos psicofarmacológicos de preparações de Passiflora edulis (maracujá). Ciênc Cult 35: 11-24.

Vogel HG, Vogel WH. 1997. Drug Discovery and Evaluation, Pharmacological Assays. Springer: Berlin, 211-212.

Wolfman C, Viola H, Paladini AC, Dajas F, Medina JH. 1994. Possible anxiolytic effects of chrysin, a central benzodiazepine receptor ligand isolated from Passiflora coerulea. Pharmacol Biochem Behav 47: 1-4.

Zanoli P, Avallone R, Baraldi M. 2000. Behavioural characterisation of the flavonoids apigenin and chrysin. Fitoterapia 71(Suppl 71): S117-S123. 